\title{
DEMERSAL FISHING ANALYSIS OF KUPANG BAY
}

\author{
J.W. Mosse and B.G. Hutubessy \\ Faculty of Fisheries Pattimura University Ambon \\ e-mail: bghutubessy@telkom.net
}

\begin{abstract}
Study on demersal fish in Kupang bay was carried for 6 months, from July 2002 to December 2002. Sampling was conducted twice a month at the ten-selected locations within the bay using different fishing gears such as gill net, bottom logline, hand line and traps. Fishes caught were stored in a icebox and transferred to the laboratory of the Fisheries Faculty of Artha Wacana Christian University, Kupang for further identification. Similarity index of fish species of the study sites was analyzed using non-metric multidimensional scaling (nMDS) of the matrix Bray Curtis similarity. A computer program PRIMER was used to perform the analysis. The result shows that there are 56 species (total catch 890 fishes) found during this study and their similarity index revealed three groups of study sites. Interestingly, it seems that these species remained to have some strong association with the existing ecosystem.
\end{abstract}

Keywords: Demersal fish, Similarity Index, Kupang Bay

\section{INTRODUCTION}

Kupang bay is surrounded by the territories of two regencies, which are the Municipal City of Kupang and the Kupang Regency. Physically, it lies between the cape of Sulamu and Oisina, covering an area of 50.000 ha that indeed has significant potential in fisheries, tourism and industry.

Various unpublished reports show that its sustainable fisheries potential is about 54,000 ton per year (Anonymous, 2000). Despite such potential only 8,417 ton per year has been fished by traditional and coastal fishers. In terms of demersal fisheries, approximation of its sustainable potential is 42,000 ton per year. All these clearly suggested that fisheries resources in Kupang Bay can not be underestimated.

Studies on the potential of demersal fish in Kupang Bay have been conducted since 1995. LaTanda and Wouthuyzen (1995) have found that there were 48 species of demersal fishes in this area. Meanwhile a census by Anonymous (2002) showed that there were about 110 species of reef fishes alone. The above studies have used visual observation technique to obtain their data. However study on demersal fish by using direct sampling based on fishing gear type has never been done before.
One of the biggest obstacle in coastal zone management of Kupang Bay is the lack of good quality of data. This includes information on the fishery potential within the area. Therefore the need for data and information such as on the composition of demersal fish based on the gear type that are operating within the bay is critical. Such data may then be used to evaluate the dynamic of fishes within their habitat as well as their ecological capability in response to fishing.

Based on the above circumstances, this study was aimed to provide pictures about the composition of demersal fish and their distribution. It is also hoped that this data will also be used as a model for spatial research in conjunction with coastal zoning of the Kupang Bay. This later objective leads by the fact that demersal fish varies according to need for specific habitat along the continental shelf.

\section{RESEARCH METHODOLOGY}

This study was done for six months begining in July 2002 and finished in December 2002. Ten sites along the coast of the bay were chosen for collection of data for this study. The sites include the water of Sulamu (1), Kera Island (2), Semau (3), Bolok (4), Tenau (5), Namosain (6), Kelapa Lima (7), Oesapa (8), Manikin (9) and Oebelo (10) (Fig 1). Generally, bottom flour of the sites 1 and 
2 are covered by hard coral and coralline algae, and white sandy as the substrate. Site 3 has similar type of bottom coverage but also surrounded by mangrove along the coast line. Sites 4 to 7 are typically covered by hard coral with patches of sea grasses. Site 8 (Oesapa) is the largest coastal area in Kupang Bay that consists of several types of bottom flour such as massive corals, reefs, sand and muddy bottoms with quite extensive mangrove vegetation. Mangrove vegetation is the main ecosystem in sites of 9 and 10 . There are several outlet of creeks along these coastal area which bring high sedimentation. Based on this fact, sampling sites of Oesapa, Manikin and Oebelo could be categorized as estuarine areas.

Fishing gears used in this study were traps, hook and line, bottom gillnet and bottom long line. Gillnet was set in the depth of 3 to $5 \mathrm{~m}$ mainly in the sandy and muddy water. Setting time was done early in the morning before dawn for 2-3 hours. This similar setting time was also made for bottom long lines to catch reef fish in 8 sites. Meanwhile hand line was operated at night in all sites. Traps were used mainly in Kera Island and set for 3 days by the local fisherman. Fish sample were collected from gillnet, long line and trap with 3 times replication, except for hand line due to the nature of its operation. Detail of these gears can be seen in Table 1.

Analysis incorporated in this study was multivariate include cluster analysis and nMDS analysis. The clustering applied was based on sites distance and percent similarity (Pielou, 1984). Nonmetric distance was chosen due to Euclidean distance between sites and species was not equal could represent positive and negative distance. By using a computer programme PRIMER, result of nMDS analysis would be depicted by h-plots consist of vectors which represent individual observation covering sites and species. The length of vectors follows the Pythagorean formula (McArdle, 1999) that shows approximate relative variance suggesting that the shortest vectors would indicate the highest similarity index. The angles between vectors show correlation value, $\mathrm{R}^{2}$ (Sheaves and Molony, 2000) which means that the two species play important role within cluster. In order to minimize potential error caused by different fish sampling regimes, analysis was performed to the 11 species that attain $75 \%$ of occurrence in all sites.

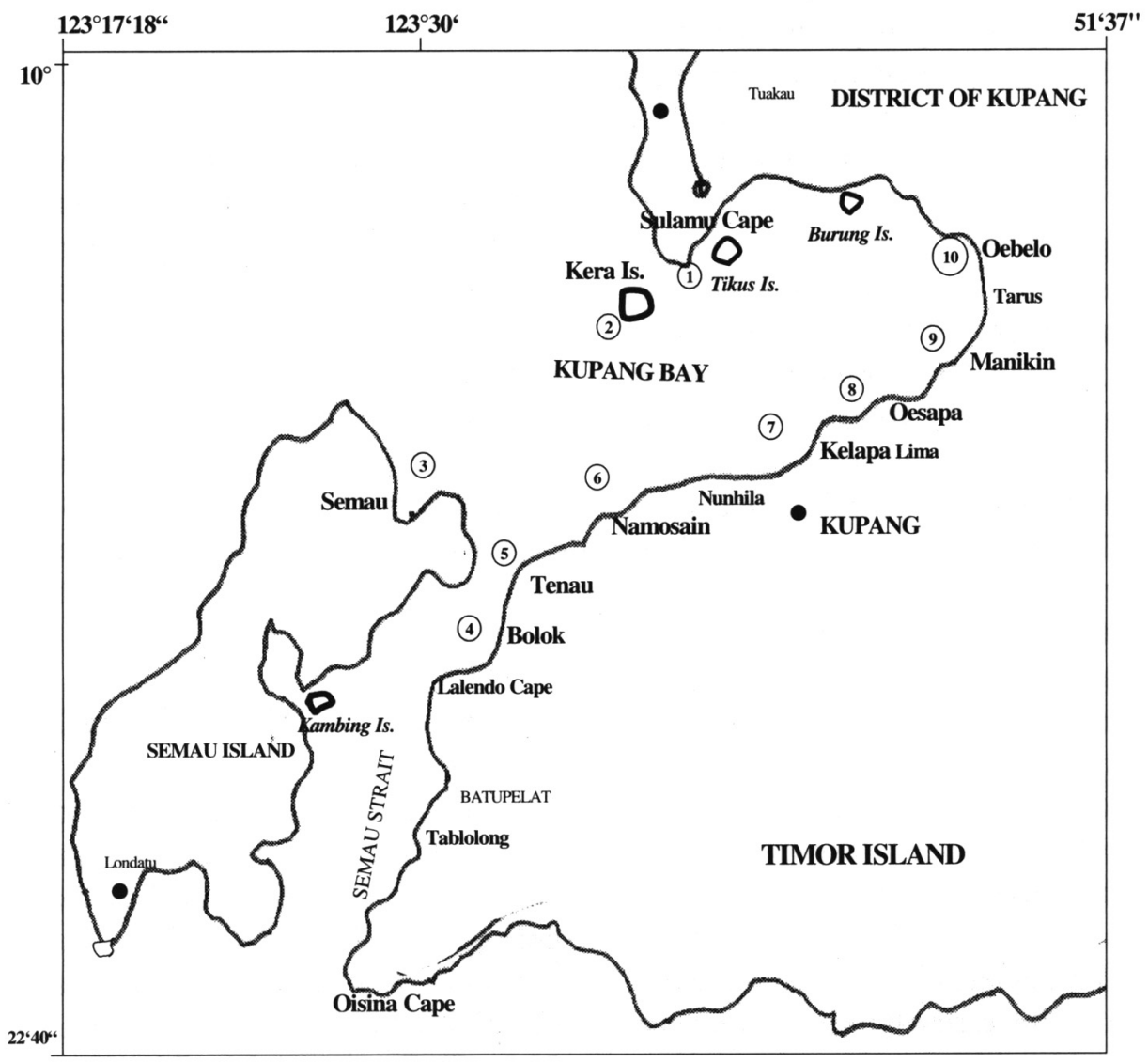

Figure 1. Map of study sites as indicated by numbers in circle ( Scale 1:250.000) 
Table 1. Fishing gears used to catch demersal fish in Kupang bay.

\begin{tabular}{|c|l|l|r|}
\hline No & \multicolumn{1}{|c|}{ Gear type } & \multicolumn{1}{c|}{ Size } & Total \\
\hline 1. & Gill net & Mesh size: $2.5 "$ & 1 unit \\
2. & Bottom Long line & Length of main line: 100 meter & 1 unit \\
3. & Hook and line & Line: No. 400 & 3 unit \\
& & No. 500 & 2 unit \\
& & No. 800 & 2 unit \\
4. & Trap & $1.5 \times 1 \times 1 \mathrm{~m} 3$ & 2 unit \\
\hline
\end{tabular}

\section{RESULTS AND DISCUSSION}

\section{Catch and fishing gear type}

In overall, 890 fishes were obtained during this study and numbers of fishes based on gear type are presented in Table 2. Of the four types of gears, hand line seems to be more effective, having high percentage of total catch of $57.86 \%$. The second rank was bottom long line that contributed $21.46 \%$, followed by gillnet and trap with the percentage out of total catch of $17.98 \%$ and $2.70 \%$ respectively. This may be due to the fact that hand line is easier, flexible, and tend to be more effective in comparison with other gears. This should also in line with the nature of other gears as they tend to be more stationary during the same time of operation.

The catch of gillnet tended to be different in terms of species caught than other gear due to gillnet setting at the mangrove areas (site 9 and 10). Fish caught were dominated by mugil followed by rabitfish, which are group of fish inhabit estuarine waters (Hutubessy, 2001). Although stingray and shark were also caught by this gear, its number was only 3 individual which may be accidentally entangled while the net was being pulled out off the water. As thus, although they may not be part of demersal fish, they were part of samples of this study. In addition, given the fact that gillnet has resulted in low diversity of fish caught, it may then be categorized as selective gear (Monintja et al., 2002).

Line fishing used in this study was handlines and bottom longline. As shown in Table 2, hand lines caught more diverse of fishes than bottom longline. This could be due to the fact of mobility and flexibility of handlines which were operated at all sampling sites. This was in contrast with the bottom longline as it tended to be operated at the coral reef areas (site 8 ) with less mobility and flexibility. Although number of catch of line fishing was higher compared with other two gears, this fishing method could be safely considered as selective gears. The use of hook size of 400, 500 and 800 for the bottom long line or hand line was an evidence of selectivity towards bigger size of fish being targeted. Thus, it is expected that under size fish population or fish that are still in immature stage or juvenile would be effectively avoided from being caught and thus protected. In contrast, unselected fishing gear will catch wide ranges of sizes of fish which then lead to the result that their chances to undertake future reproductive turn will be cut off. It is also argued that bottom gillnet and hand line would have less negative impact on the bottom fishes.

Technically, trap is specifically designed to trap fishes out of its stationary position. It is believed that this unique gear will allow fish to enter the main body of the trap through two sides of opening mouth. Once fishes get inside, they tend to remain calm perhaps, because they may get protected from any threat or due to the availability of food supply inside the trap. This is especially true if bait is used. Generally, not many fishes may get trapped at once, given the fact that most of demersal fish tend to be more solitary (Russ, 1991). They also show strong site attach behavior which means that other fishes may thus avoid the same trap. Given this, therefore we could not expect high number of catch from traps as shown in this study where only 24 individual fishes out of 890 caught by traps in Kera Island. From the species perspective, only 3 species were successfully retained by this fishing gear. This is slightly in contrast to the fact of high abundance of demersal fishes inhabiting Kera Island as reported by 
Table 2. Catch based on fishing gear type

\begin{tabular}{|c|c|c|c|c|c|}
\hline NO & GEAR TYPE & LOCATION & FISH SPECIES & $\begin{array}{c}\text { NUMBER OF } \\
\text { CATCH } \\
\text { (Individual) }\end{array}$ & $\begin{array}{c}\text { \% OF } \\
\text { CATCH }\end{array}$ \\
\hline \multirow[t]{2}{*}{1} & Gillnet & $\begin{array}{l}\text { Oesapa } \\
\text { Manikin } \\
\text { Bolok } \\
\text { Oebelo }\end{array}$ & $\begin{array}{l}\text { Shark } \\
\text { Stingray } \\
\text { Marine catfish } \\
\text { Mugil } \\
\text { Rabitfish } \\
\text { Threathfin bream }\end{array}$ & $\begin{array}{c}2 \\
3 \\
2 \\
74 \\
19 \\
60 \\
\end{array}$ & \\
\hline & & & Total & 160 & 17.98 \\
\hline \multirow[t]{2}{*}{2} & Bottom long line & $\begin{array}{l}\text { Oesapa } \\
\text { Kelapa Lima } \\
\text { Sulamu } \\
\text { Kera Island } \\
\text { Namosain } \\
\text { Semau } \\
\text { Tenau } \\
\text { Bolok } \\
\end{array}$ & $\begin{array}{l}\text { Trevally } \\
\text { Eel } \\
\text { Grouper } \\
\text { Banded grunt } \\
\text { Snapper } \\
\text { Emperor } \\
\text { Threadfin bream }\end{array}$ & $\begin{array}{c}15 \\
2 \\
13 \\
52 \\
17 \\
9 \\
83\end{array}$ & \\
\hline & & & Total & 191 & 21.46 \\
\hline \multirow[t]{2}{*}{3} & Hand line & $\begin{array}{l}\text { Oesapa } \\
\text { Kelapa Lima } \\
\text { Manikin } \\
\text { Sulamu } \\
\text { Kera Island } \\
\text { Namosain } \\
\text { Semau } \\
\text { Tenau } \\
\text { Bolok } \\
\text { Oebelo }\end{array}$ & $\begin{array}{l}\text { Stingray } \\
\text { Shark } \\
\text { Eel } \\
\text { Soldier fish } \\
\text { Grouper } \\
\text { Trevally } \\
\text { Banded grunter } \\
\text { Red Snapper } \\
\text { Emperor } \\
\text { Threadfin bream } \\
\text { Goatfish } \\
\text { Parrotfish } \\
\text { Snakehead } \\
\text { Rabitfish } \\
\text { Triggerfish } \\
\text { Surgeon fish } \\
\text { Sole fish }\end{array}$ & $\begin{array}{c}2 \\
1 \\
4 \\
8 \\
21 \\
25 \\
101 \\
112 \\
44 \\
68 \\
35 \\
1 \\
32 \\
10 \\
40 \\
10 \\
1 \\
\end{array}$ & \\
\hline & & & Total & 515 & 57.86 \\
\hline \multirow[t]{3}{*}{4} & Trap & Kera Island & $\begin{array}{l}\text { Rabitfish } \\
\text { Grouper } \\
\text { Triggerfish }\end{array}$ & $\begin{array}{c}6 \\
8 \\
10 \\
\end{array}$ & \\
\hline & & & Total & 24 & 2.70 \\
\hline & & & TOTAL CATCH & 890 & 100.00 \\
\hline
\end{tabular}

LaTanda and Wouthuyzen (1995). Although further study is needed, such low species diversity may enable one to suggest that traps could be categorized as Eco-friendly fishing techniques (see Monintja et al, 2002).

In overall, it is interesting to note that the four fishing gear types used in this study could not just be categorized as environmentally friendly gears, but also affordable and technically require only minimal effort.

\section{Dendogram and nMDS}

Figure 2 is a dendogram depicting similarity index of sampling sites. Of the ten study sites, similarity of fish species tends to be in groupings. We found three groups of fish where the first group with high similarity index is those from Kera Island, Sulamu, Tenau and Namosain. Meanwhile second group represented by sample from Semau, Bolok, and Kelapa Lima. The last group with the lowest similarity index was those in Oesapa, Manikin and Oebelo. First and second group have similarity 


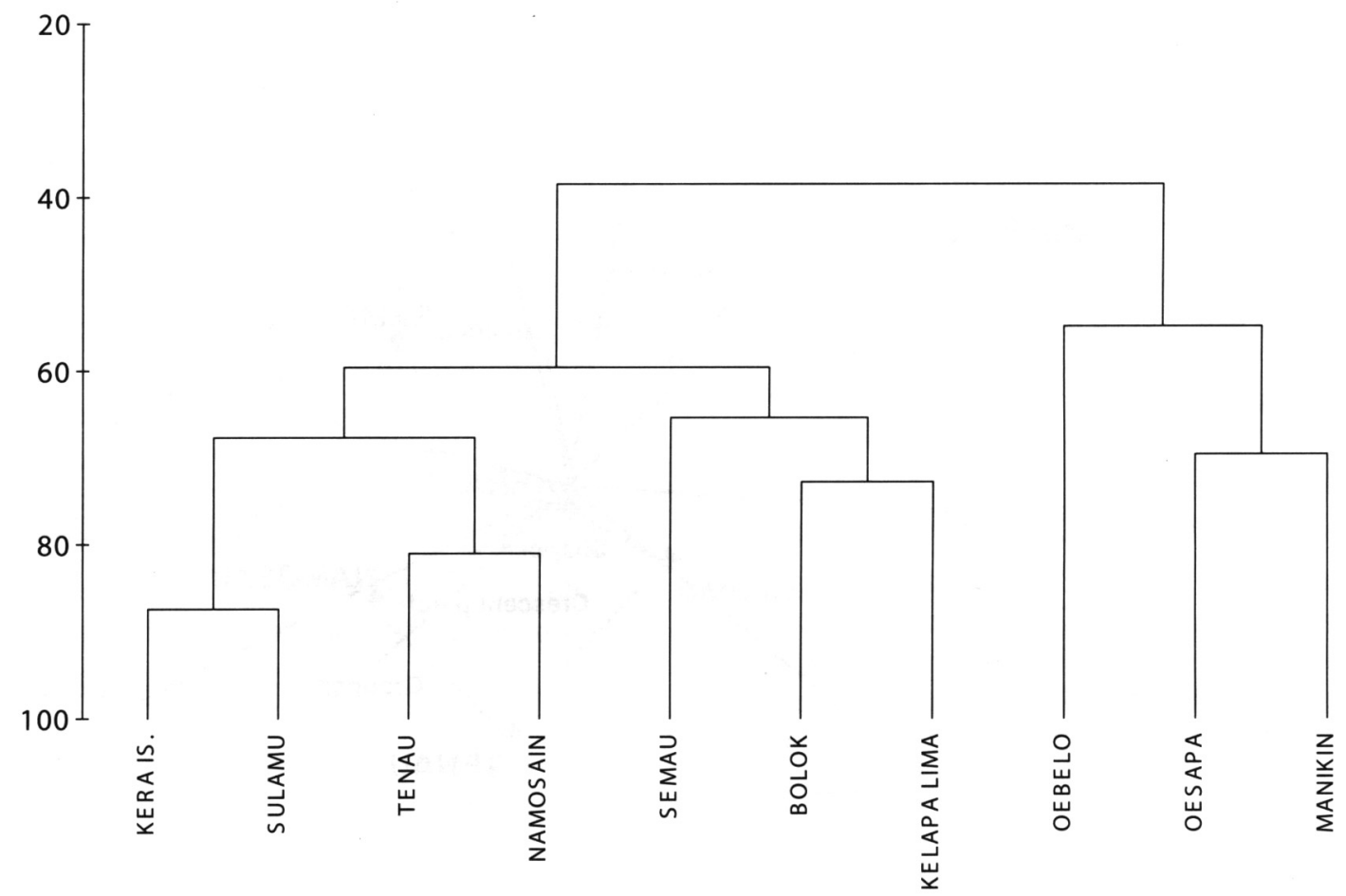

Figure 2. Dendogram of similarity of demersal fish species caught from Kupang bay in July - December 2002

index of less than $40 \%$ however they also lack of similarity with the third group.

The difference between third group with other groups was believed to be due to the effect of differences in coastal ecosystem. Along the coast of Oesapa, Manikin and Oebelo, mangrove is the most important ecosystem. It is believed that rivers and their tributaries in these three sites unload their materials that have significant impact due to the augmentation of sediment along their coasts (Anonym, 2003). Given this fact, it is not surprising to find that fish species inhabiting these sites tend to be those that show similar adaptation. In addition, these sites are also considered to be a significant estuarine ecosystem as indicated by the high numbers of economic important species such as mugil (74 individual) and threadfin bream (60 individual). Hutubessy (2001) have argued that estuarine ecosystem is a recruitment area for various economically important fish species including those of demersal one like snappers Lutjanus sp, emperor Lehtrinus sp, groupers Epinephelus sp. These species inhabit this area especially at the juvenile stage as their before migrate into the deep water for spawning. Therefore, although these species were not found during this study in this cluster (gillnet mesh size is large for catching juvenile stage), however, it is believed that these mangrove area support the adjacent coral reef.

In terms of similarity index of the first group, the highest index was at Kera Island and Sulamu that was more than $80 \%$. Both of these sites are in fact close to each other and have relatively similar bottom structure. In this cluster, as shown in Figure 3, the highest similarity index of fish was snapper, followed by perch crescent, grouper and triggerfish. The angles of their vectors showed that they have good relationship, probably in sharing for space and food. Perch crescent is scale feeder inhabiting coralline algae while triggerfish is herbivorous. Snapper and grouper are predators, however they have separate home range where snapper more conspicuous in Kera Island while groupers was in Tenau. Meanwhile in Namosain, trigger fish (Balistidae) found to be more conspicuous. The tendency of the vector of triggerfish to the Namosain site should also add to the above fact (Fig. 3). Although, evidence that fishing could change competition level between coral reef fishes remains scant (Russ, 1991), there have been evidences that support such notion (Bohnsack, 1993; Koslow et al., 1988). Though further detail study is required, it seems that present 


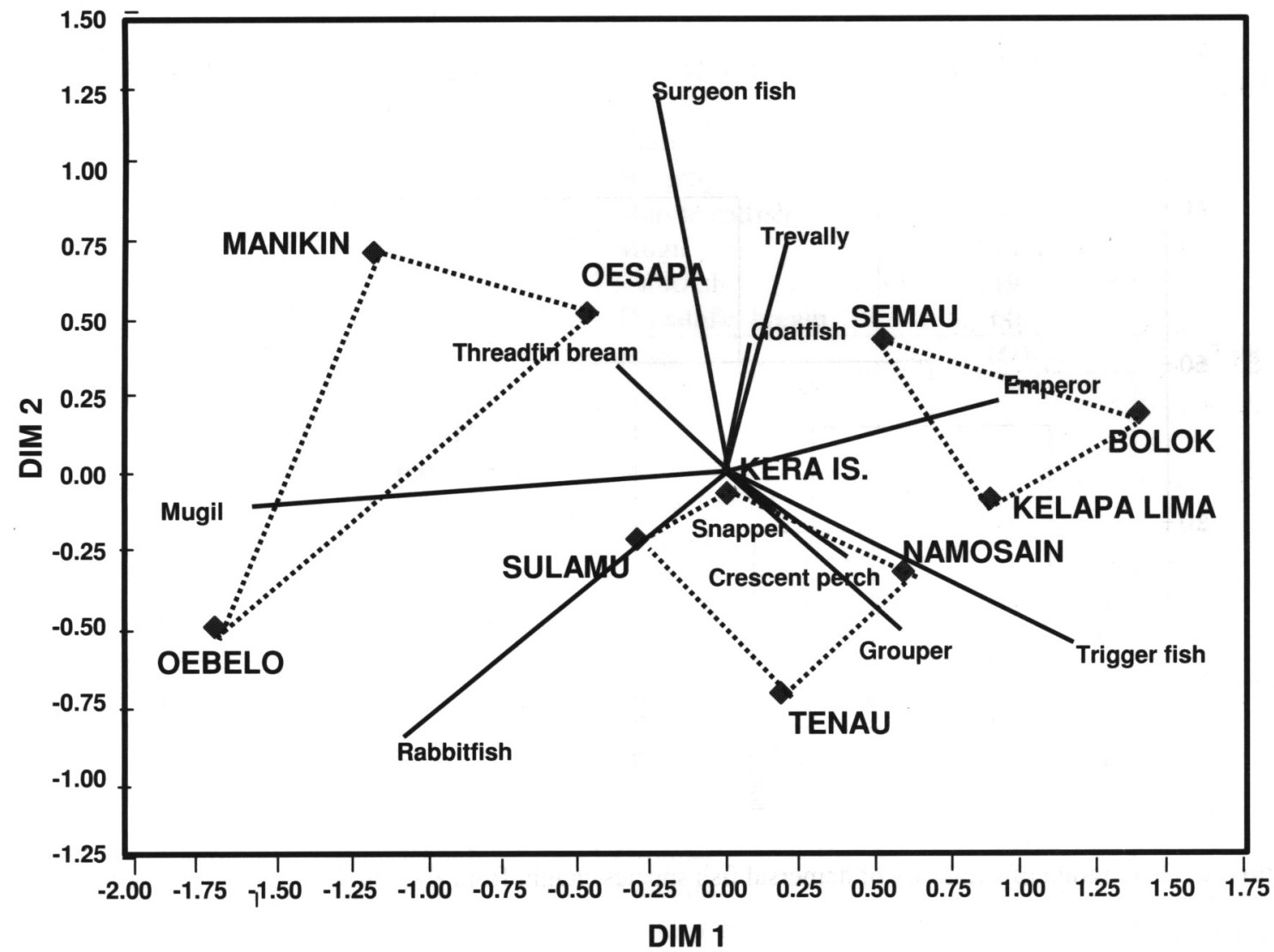

Figure 3. Plot of nMDS with stress 0.09. Distribution of demersal fish at study sites in Kupang bay based on Bray Curtis Similarity using four root transformation data.

conspicuousness of trigger fish in Namosain site may indicate that top competitor have been fished.

Of the second group covering Bolok and Kelapa Lima sites, similarity index was closed to $70 \%$. In comparison with Semau site, however, the similarity index was $60 \%$ while fish species that conspicuous in these three sites included goatfish and emperor (Fig. 3). As a mater of fact, these two species have been known as marine migrant species entering mangroves and estuarine ecosystem during part of their life cycles (Blaber, 1997). If this is the case then one might argue that existing mangroves ecosystem in these two locations is very important yet the scale only take small proportion of the whole coastal areas. As shown in Figure 3, surgeonfish, trevally and rabitfish have shown little association to the study sites. This is indicated by the vector line of these three species that are long and separated from the coordinate point. It is known that trevally (Caranx $s p$ ), surgeonfish (Acanthurid) and rabitfish (Siganids) are grouped as reef fishes, however they exhibit wide home range that cover also sea grass beds (Mosse and Hutubessy, 1996).

It seems that catch of the bottom fishes based on the specific species are dependent on the surrounding ecosystem. This includes organic mud in the bottom deposits, estuarine conditions associated with river mouths, the occurrence of mangroves habitat and patches of rocky reef. All these would chiefly determine fish community diversity along the continental shelf regardless of a distance (Longhurst and Pauly, 1987) As such knowledge and information concerning coastal ecosystem and the role of the adjacent water is crucial to maintaining long-term development of demersal fishing in the area. This should trigger further studies in order to understand their regular presences and seasonal abundance that would support fishing operation. In addition, this study may also contribute to the efficiency of fishing of target species. It should thus reduce non-targeted species while increase catch of the targeted species. 


\section{CONCLUSION}

Based on the similarity index, fish species found in this study seems to reflect specific type of habitat and ecosystem available such as mangroves, coral reefs and estuaries. Snapper (Lutjanus sp.) play important role in coral reef (cluster of first group), emperor (Lethrinus sp.) at the cluster of coral reef adjacent to mangrove beds and mugil (Mugil sp.) at estuarine cluster.

Ecosystem degradation has occurred in some location as indicated by presence of some low level of competitors. However some conspicuous economically important species remain to be found within the Kupang Bay. In line with this fact, careful attention by various users of the resources is critical and urgently needed.

Acknowlegment. We thank Roy Manafe who has been involved in fish sampling in Kupang Bay and handlines fishermen who has provided us with such supported information. This analysis was also corrected by Fisheries Faculty staff of Artha Wacana Christian University of Kupang.

\section{REFERENCES}

Blaber, S.J.M. 1997. Fish and fisheries of tropical estuaries. Chapman \& Hall, London. $367 \mathrm{pp}$

Bohnsack, J.A. 1993. Marine reserves. They enhance fisheries, reduce conflicts, and protect resources. Oceanus $36: 63$ - 71
Hutubessy, B.G. 2001. Pattern of fish assemblage, age structure and recruitment of tropical estuarine fish. MSc Thesis. Dept. Mar. Biol. James Cook University of North Queensland, Australia

Koslow, J.A, F. Hanley, R. Wicklund. 1988. Effect of fishing on reef fish communities at Pedro Bank and Port Royal Cays, Jamaica. Mar.Eco.Prog.Ser 43: $201-212$

LaTanda dan S. Wouthuyzen. 1995. Census of reef fishes from Kupang Bay. In: S. Wouthuyzen (Eds). The status of coastal zone of Kupang Bay, . BPPSL, P3O, LIPI Ambon.

Longhurst, A.R. and D. Pauly. 1987. Ecology of tropical oceans. Academic Press, Inc, New York. 406 pp

Monintja, D., S. Marjani \& Sarminto. 2002. Metode seleksi teknologi penangkapan ikan yang ramah lingkungan dan berkelanjutan di kawasan terumbu karang. Konferensi nasional III 2002. Pengelolaan Sumberdaya Pesisir dan Laut Indonesia. Prosiding. Bali. Page 22-32.

Mosse, J.W. and B.G.Hutubessy, 1996. Age and growth of the siganid (Siganus canaliculatus) from Ambon bay as indicated by growth increments of sagitta. Perairan Maluku dan Sekitarnya, vol 10(1996):23-34

Pielou, E.C. 1984. The interpretation of ecological data. A primer on classification and ordination. John Willey \& Sons, New York: 263 pp

Russ, G.R. 1991. Coral Reef Fisheries: Effects and Yields. In: Sale, P.F. (Eds). The Ecology of Fishes on Coral Reefs. Page 601-634

Sheaves, M. and B. Molony. 2000. Short sircuit in the mangrove food chain. Mar. Ecol. Prog. Ser. 199: 97 -109 . 